\title{
Supercritical Technology Applied to the Production of Bioactive Compounds: Research Studies Conducted at LASEFI from 2009 to 2013
}

\author{
Giovani L. Zabot, Moyses N. Moraes, M. Angela A. Meireles* \\ LASEFI/DEA/FEA (School of Food Engineering), UNICAMP (University of Campinas), RuaMonteiroLobato, 80, Campinas-SP, \\ CEP:13083-862, Brazil
}

\begin{abstract}
This paper presents a review of the scientific research studies conducted in the period from 2009 to 2013 at LASEFI (Laboratory of Supercritical Technology: Extraction, Fractionation and Identification of Vegetal Extracts) Department of Food Engineering (DEA)/School of Food Engineering (FEA), University of Campinas (UNICAMP)/Brazil. The current research projects revolve around the use of supercritical fluids in several areas. One of these projects covers the production and encapsulation of micro- and nano-bioactive compounds using Supercritical Antisolvent (SAS) and Supercritical Fluid Extraction from Emulsions (SFEE) techniques. Another project is focused on obtaining anthocyanins, carotenoids, flavonoids, volatile oils and tocotrienols by applying supercritical technology. The experiments involve the determination of process parameters and the chemical characterization of the extracts. The hydrolysis of agroindustrial co-products using sub/supercritical water $+\mathrm{CO}_{2}$ for sugar production and second generation ethanol production are also performed. Recently, a home-made multipurpose system containing two extractors of $1 \mathrm{~L}$ each with different shapes was assembled to evaluate the influence of the bed geometry on the kinetic extraction yields and on the chemical composition of the extracts. In yet another project, online processes that produce and encapsulate vegetal extracts of high added value are coupled with supercritical fluid extraction (SFE) of bioactive compounds in continuous mode. These projects are performed using SFE extraction systems equipped with $0.005 \mathrm{~L}-5 \mathrm{~L}$ extractors, 1 hydrolysis systems containing a $0.05 \mathrm{~L}$ reactor and 1 micronization systems containing a $0.65 \mathrm{~L}$ reactor. In the past 4 years, 57 articles and over 100 conference papers (full length and abstracts) have been published. A large number of botanic matrices have been selected for study due to their functional properties and their potential applications in the food and pharmaceutical industries.
\end{abstract}

Keywords Supercritical fluid extraction, Botanic matrices, Bioactive compounds, Hydrolysis, Micronization

\section{Introduction}

Supercritical technology is studied in several international research centers, where some studies are mentioned [1-15]. This technology utilizes renewable solvents, such as $\mathrm{CO}_{2}$, and is a green technology because supercritical processes avoid or minimize environmental damage. The main characteristic of this technology is the use of solvents above or near their critical conditions for temperature and pressure. A solvent in a supercritical state easily penetrates inside a solid matrix and solubilizes the solute even when it is strongly attached to the cellular wall.

The availability of substantial amounts of raw materials in

* Corresponding author:

meireles@fea.unicamp.br (M. Angela A. Meireles)

Published online at http://journal.sapub.org/fph

Copyright (C) 2014 Scientific \& Academic Publishing. All Rights Reserved regions near the place of manufacture contributes to the development of supercritical fluid processes and improves their economic feasibility for industrial applications. This fundamental point is satisfied in several regions of Brazil. This country has one of the highest levels of biodiversity worldwide, which allows the production of low-cost raw materials.

In the latest 29 years, LASEFI (Laboratory of Supercritical Technology: Extraction, Fractionation and Identification of Vegetal Extracts) has been developing processes using supercritical technology. Several patents have been registered, and many scientific research studies have been published in Journals and Conference Proceedings (44 full length and 65 abstracts). Therefore, the objective of this review is to present the knowledge acquired from the recent results obtained in the laboratory and to provide a brief discussion of the advances that occurred from 2009 to 2013. 


\begin{tabular}{|ll|}
\hline Nomenclature \\
SFE & Supercritical fluid extraction \\
PLE & Pressurized liquid extraction \\
LPSE & Low pressure solvent extraction \\
HPCDAE & High pressure CO $_{2}$-assisted extraction \\
UAE & Ultrasound assisted extraction \\
ABE & Agitated bed extraction \\
GYIs & Global yield isotherms \\
OECs & Overall extraction curves \\
EY & Extraction yield \\
UV-vis & Spectrophotometry \\
GC-MS & Gas chromatography - mass spectrometry \\
GC-FID & Gas chromatography coupled to flame ionization \\
HPLC & detector \\
TLC & High performance liquid chromatography \\
DSC & Differential scanning calorimetry \\
$\mathrm{X}_{0}$ & Total yield of the soluble matter in the solvent \\
TPC & Total phenolic content \\
TFC & Total flavonoid content \\
Aa & Antioxidant activity \\
COM & Cost of manufacturing \\
TMA & Total monomeric anthocyanin \\
DPPH & 2,2-Diphenyl-1-picrylhydrazyl \\
GAC & Gallic acid content \\
$d_{E}$ & Extractor/reactor internal diameter \\
$H_{E}$ & Extractor/reactor height \\
$V_{E}$ & Extractor/reactor volume \\
$V_{S}$ & Separator volume \\
&
\end{tabular}

\section{Research Studies Conducted at LASEFI from 2009 to 2013}

Some of the current scientific investigations focused on supercritical technology being carried out by LASEFI's research group are as follows: the extraction of bioactive compounds from botanic matrices and the evaluation of the process parameters, the production of micro- and nano-encapsulated compounds using Supercritical Antisolvent (SAS) and Supercritical Fluid Extraction from Emulsions (SFEE) techniques and the hydrolysis of agroindustrial co-products using sub/supercritical water + $\mathrm{CO}_{2}$ for the production of sugars that can be eventually utilized for second-generation ethanol production. The laboratory has seven systems to perform these types of experiments. Table 1 and Figure 1 present the characteristics of each one of the systems belonging to LASEFI.

Item 1 (SFE-2×1L, Figure 1-1) is a home-made system containing two extractors of $1 \mathrm{~L}$ each with different geometries. It is a multipurpose unit that can be used for extracting bioactive compounds in continuous mode from several raw materials. Item 2 (SFE-I, Figure 1-2) is also a system that was assembled at LASEFI. It is used when the addition of co-solvents is required during extraction. Both Items 2 and 5 (PLE-I, Figure 1-5) can be used for PLE.

Item 3 (SFE-Spe-ed, Figure 1-3) is a commercial unit for extraction (Applied Separations, 7071, Allentown, USA) and can be used with extractors with volumes from $0.005 \mathrm{~L}$ to $0.29 \mathrm{~L}$. Item 4 (SFE- $2 \times 5 \mathrm{~L}$, Figure 1-4) is the largest unit owned by LASEFI. The respective extraction system possesses two extractors of $5 \mathrm{~L}$ each (Thar Technologies, Pittsburgh, USA) arranged in parallel and three 1-liter separators operating in series.

Item 6 (ARADIME, Figure 1-6) is a system that enables the development of several types of processes using pressurized fluids such as sub/supercritical fluid extraction with or without co-solvent and the production of particles via RESS or SAS. The integration of unit operations is one of the recent research topics undertaken by the scientists at LASEFI. As a result of this research, the HYDRO system (Item 7, Figure 1-7) was integrated with upstream extraction units to achieve biomass hydrolysis.

\subsection{Extracting Bioactive Compounds}

Several botanic matrices that contain compounds with potential applications in the food, chemical and pharmaceutical industries have been studied. One of these compounds is $\beta$-ecdysone, a saponin with therapeutic properties found in Brazilian ginseng (Pfaffia glomerata). Leal et al [16] obtained Brazilian ginseng extracts using supercritical $\mathrm{CO}_{2}$ in the SFE-I system. According to their results, the extract's antioxidant activity was a function of the extraction conditions, where the largest antioxidant activity was obtained at $30 \mathrm{MPa}$ and $303 \mathrm{~K}$.

Table 1. Characteristics of LASEFI's systems for SFE, PLE, micronization and hydrolysis

\begin{tabular}{|c|c|c|c|c|c|c|c|}
\hline \multirow[t]{2}{*}{ Item } & \multirow[t]{2}{*}{ System } & \multicolumn{3}{|c|}{$\begin{array}{c}\text { Characteristics of the } \\
\text { extractors/reactors }\end{array}$} & \multirow{2}{*}{$\begin{array}{l}\text { Solvent commonly } \\
\text { used }\end{array}$} & \multirow[t]{2}{*}{ Co-solvent } & \multirow{2}{*}{$\begin{array}{c}\text { Separators } \\
V_{S}(L)\end{array}$} \\
\hline & & $\mathrm{d}_{\mathrm{E}}(\mathrm{cm})$ & $\mathrm{H}_{\mathrm{E}}(\mathrm{cm})$ & $\mathrm{V}_{\mathrm{E}}(\mathrm{L})$ & & & \\
\hline \multirow{2}{*}{1} & \multirow{2}{*}{ SFE-2×1L (Extraction) } & 5.7 & 21.2 & 1 & \multirow{2}{*}{$\mathrm{CO}_{2}$} & \multirow{2}{*}{ No } & \multirow{2}{*}{ NP } \\
\hline & & 7.7 & 40.7 & 1 & & & \\
\hline 2 & SFE-I (Extraction) & 3.4 & 40.5 & 0.37 & $\mathrm{CO}_{2}$ & Yes & NP \\
\hline \multirow{3}{*}{3} & \multirow{3}{*}{ SFE-Spe-ed (Extraction) } & 5.4 & 12.3 & 0.28 & \multirow{3}{*}{$\mathrm{CO}_{2}$} & \multirow{3}{*}{ No } & \multirow{3}{*}{$\mathrm{NP}$} \\
\hline & & 2.0 & 6.3 & 0.02 & & & \\
\hline & & 2.0 & 1.6 & 0.005 & & & \\
\hline 4 & SFE-2×5L (Extraction) & 10.2 & 61.4 & $2 * \times 5$ & $\mathrm{CO}_{2}$ & Yes & $3 * \times 1000$ \\
\hline 5 & PLE-I (Extraction) & 2.0 & 2.0 & 0.006 & Ethanol/Water & No & NP \\
\hline 6 & $\begin{array}{c}\text { ARADIME } \\
\text { (Micronization) }\end{array}$ & 7.0 & 16.8 & 0.65 & $\mathrm{CO}_{2}$ & Yes & NP \\
\hline 7 & HYDRO (Hydrolysis) & 2.8 & 8.4 & 0.05 & Water/ $\mathrm{CO}_{2}$ & Yes & $\mathrm{NP}$ \\
\hline
\end{tabular}

*: indicates the number of extractors/reactors or separators belonging to the system; NP: Not present. 
A patent by Meireles et al [17], PI0900551-0A2, was deposited with the Brazilian National Institute of Industrial Property (INPI). The patent presents a supercritical fluid extraction process for active compounds from Brazilian ginseng roots. The described process can be performed in continuous or semi-continuous mode. The choice of one extraction mode over the other depends on the number of extractors and on the control devices that make up the process operation plant.

Takeuchi et al [18] extracted phenolic compounds from macela (Achyroclinesatureioides) using mixtures of $\mathrm{CO}_{2}$ plus ethanol using the SFE-I system (Item 2, Figure 1). The addition of a co-solvent provided another means of manipulating the solvent selectivity, improved the extraction yield and intensified the functional properties of the extracts. High and stable antioxidant activities were obtained.

Phenolic compounds were extracted from pomegranate
(Punicagranatum). The compounds present in this fruit show anti-inflammatory and antimicrobial properties. The supercritical fluid extraction was efficient because the extract presented a high TPC (389 mg.g $\left.{ }^{-1}\right)$. The appropriate operating conditions were $30 \mathrm{~Pa}$ and $323 \mathrm{~K}$ [19].

The extraction of antioxidant compounds from jabuticaba (Myrciaria cauliflora) byproducts was investigated using SFE with a co-solvent. The SFE-I system has a co-solvent line (as seen in Scheme 1) and was used for performing the experimental assays. A greater extraction yield was achieved at $30 \mathrm{MPa}$ and $333 \mathrm{~K}$, resulting in $25 \mathrm{~g}$ extract $/ 100 \mathrm{~g}$ raw material. However, the highest antioxidant activity was obtained at $20 \mathrm{MPa}$ and $323 \mathrm{~K}$. An increase in temperature resulted in decreased recovery of the antioxidant compounds, indicating the extraction of undesirable compounds. This is likely because most of the antioxidant compounds are unstable and highly susceptible to thermal degradation [20].
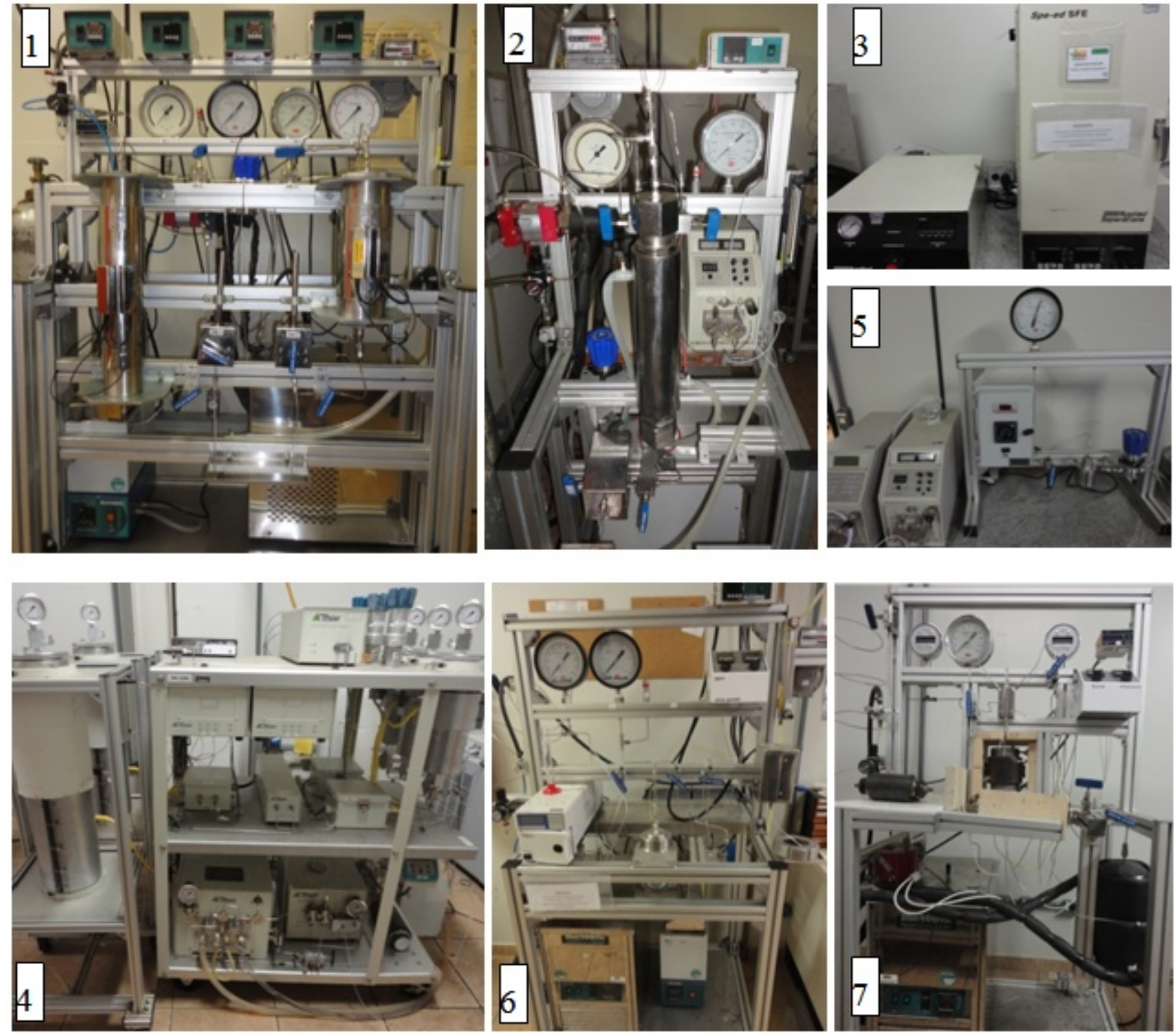

Figure 1. Supercritical technology unitsbelonging to LASEFI for extraction: (1) SFE-2×1L; (2) SFE-I; (3) SFE-Spe-ed; (4) SFE-2 $\times 5$ L; for micronization: (5) ARADIME; and for hydrolysis: (6) HYDRO 


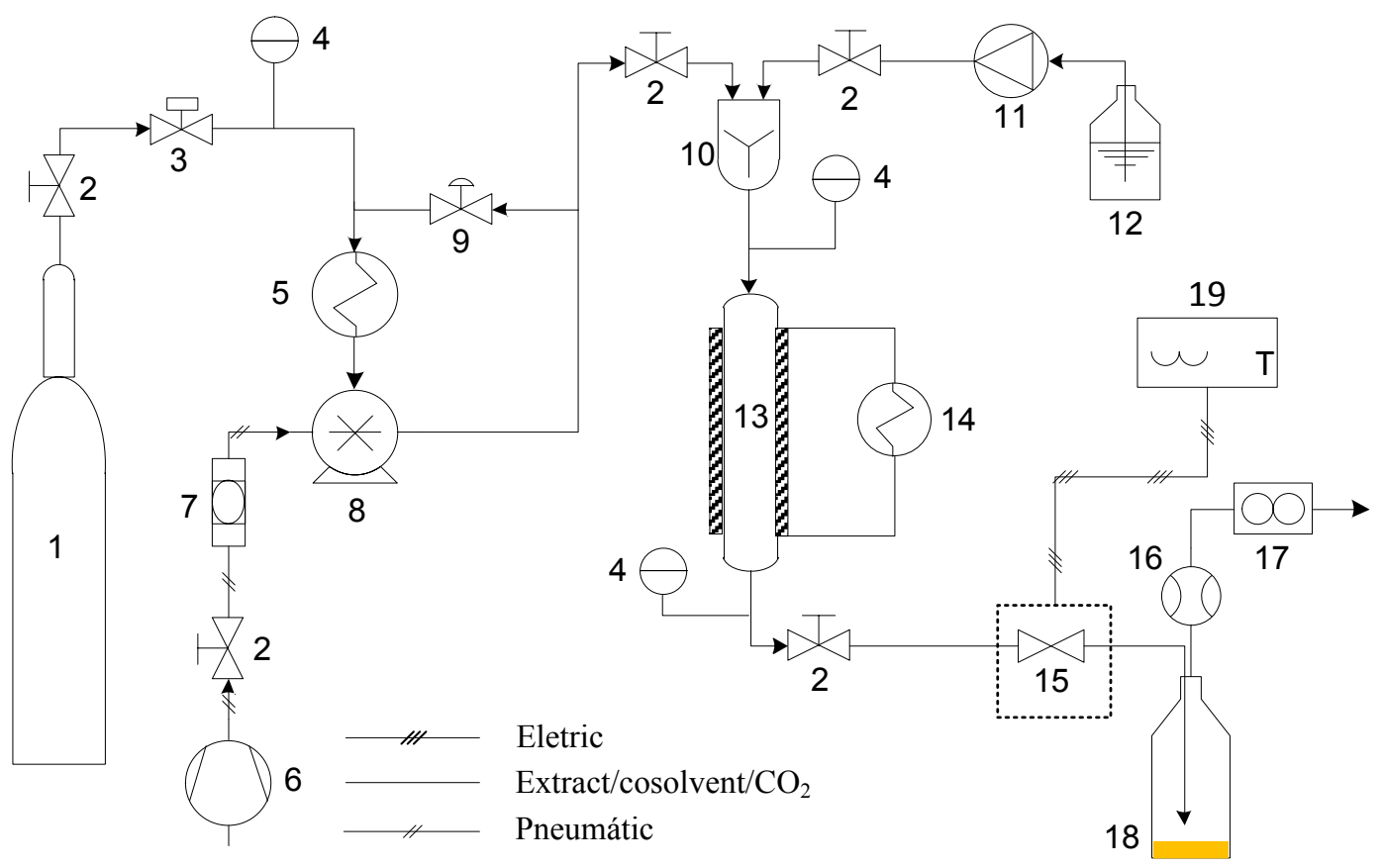

\begin{tabular}{|c|c|}
\hline \multicolumn{2}{|c|}{ List of equipments } \\
\hline 1 & $\mathrm{CO}_{2}$ reservoir \\
\hline 5 & Cooling bath \\
\hline 6 & Air compressor \\
\hline 8 & Air-driven $\mathrm{CO}_{2}$ pump \\
\hline 11 & Air driven cosolvent pump \\
\hline 12 & Cosolvent reservoir \\
\hline 13 & Extraction cell \\
\hline 14 & Heating bath \\
\hline 18 & Extract collecting vessel \\
\hline
\end{tabular}

\begin{tabular}{|c|c|}
\hline \multicolumn{2}{|c|}{ List of valves/instruments } \\
\hline 2 & Blocking valve \\
\hline 3 & Non-return valve \\
\hline 4 & Pressure gauge \\
\hline 7 & Air filter \\
\hline 9 & Back Pressure Regulator \\
\hline 10 & Mixer \\
\hline 15 & Micrometering valve \\
\hline 16 & Flowmeter \\
\hline 17 & Flow totalizer \\
\hline
\end{tabular}

Scheme 1. Flow diagram for the SFE-I experimental apparatus for extraction, including cosolvent feed system (adapted from Veggi [21])

Another patent (PI0903275-4A2) developed at LASEFI was deposited by Meireles and Rosa [22] with the INPI. This patent mentions the extraction and purification process of artemisinin from the solid mass of Artemisia annua using supercritical technology. The extraction process is divided into three stages. The first stage entails the contact and dissolution of the solid particulate mass in supercritical $\mathrm{CO}_{2}$ inside the extractor. The second stage aims to obtain the purified extract and requires contact between the $\mathrm{CO}_{2}$ and the vegetal extract dissolved in a fixed polar phase in a fractionation column. The third stage, elution, involves contact between the $\mathrm{CO}_{2}$ and co-solvent mixture with a fixed polar phase in a second fractionation column.

Scheme 2 shows the flow diagram of the SFE-Spe-ed system (Applied Separations, model 7071, Allentown, USA). This unit is an efficient and simple apparatus used to obtain various target compounds. SFE of chamomile (ChamomillarecutitaL.) extract was studied in the SFE-Spe-ed system using a $0.29 \mathrm{~L}$ extractor. A yield of approximately $3.5 \mathrm{~g}$ extract $/ 100 \mathrm{~g}$ raw material was obtained. Compounds such as en-in-dicycloether and cis- $\beta$-farnesene were identified in the extracts. Mathematical modeling and optimization were carried out to determine the optimum conditions that maximize the extract amount. The effect of particle diameter on extraction yield was also investigated. The results show that, for chamomile, the extraction yield is a weak function of particle diameter. Nevertheless, the other process parameters, temperature and pressure, strongly influenced the extraction yield. Increasing either of these parameters led to enhanced extraction of bioactive compounds from chamomile [23].

SFE of annatto (Bixaorellana L.) was performed in the SFE-Spe-ed apparatus to obtain an extract rich in tocotrienols and defatted bixin-rich seeds. The highest extraction yield $(2.2 \mathrm{~g}$ extract $/ 100 \mathrm{~g}$ raw material) was reached at $40 \mathrm{MPa}$ and $333 \mathrm{~K}$. In this study, cycles of $\mathrm{CO}_{2}$ pressurization/depressurization were tested, but their influences on the bixin yield were negligible. The effects of pressure release on modifying the cell membrane due to rapid gas expansion did not provide an improvement in the process efficiency [24].

Another piece of equipment belonging to LASEFI is the SFE-2 $\times 1 \mathrm{~L}$ system (Scheme 3), which includes two extractors of $1 \mathrm{~L}$ each operating in parallel. The system was assembled to test and validate an extraction process for bioactive compounds in continuous mode. This 
configuration allows vegetal extracts to be obtained uninterruptedly, and thus, the productivity can be improved and the costs of production can be reduced. However, operating in this configuration requires the kinetic curves of both extractors to be identical, despite their different geometries. Currently, experimental assays are being carried out to establish the operation criteria and process parameters that will enable comparison of the extraction curves in these extractors. The purpose is to obtain equals mass transfer rates for both extractors. Thus, one of the criterion can be the maintenance of the $\mathrm{S} / \mathrm{F}$ (mass of solvent/mass of raw material) ratio and the extraction time constants. The review by Zabotet al [26] provides detailed information about the influence of extractor geometries on the kinetic profiles of the extraction.

To assess the feasibility of SFE in industrial applications, knowledge obtained from laboratory scale experiments should be used to conduct a pilot run. Therefore, scale-up criteria that are able to reproduce the overall extraction curves (OEC) need to be defined.
Prado et al [27] utilized the available equipment at LASEFI and studied processes involving SFE scale up. The investigations aimed to obtain extracts from clove (Eugenia caryophyllus) and sugarcane residue. The SFE-Spe-ed system (extractor of $0.29 \mathrm{~L}$ ) and the SFE- $2 \times 5 \mathrm{~L}$ system (Scheme 4) were used in this research. The proposed scale-up criteria consisted of maintaining the $\mathrm{S} / \mathrm{F}$ ratio and the extraction time constants. Considering a 15 -fold increase in the raw material mass for the SFE- $2 \times 5 \mathrm{~L}$, the solvent mass was also increased 15 times. Operationally, the solvent mass flow rate was 15 times higher and the extraction time was maintained. Adopting these simple criteria of maintaining the $\mathrm{S} / \mathrm{F}$ ratio and the extraction time constants resulted in the appropriate replication of the kinetic profiles of the OEC in the scale-up experiment. Similar yields were reached in both the SFE-Spe-ed (I) and the SFE- $2 \times 5 \mathrm{~L}$ (II) system. The yields of clove extracts were $15 \mathrm{~g} / 100 \mathrm{~g}$ (I) and $14.5 \mathrm{~g} / 100 \mathrm{~g}$ (II). The yields of sugarcane residue were $2.5 \mathrm{~g} / 100 \mathrm{~g}$ (I) and 2.8 $\mathrm{g} / 100 \mathrm{~g}$ (II).

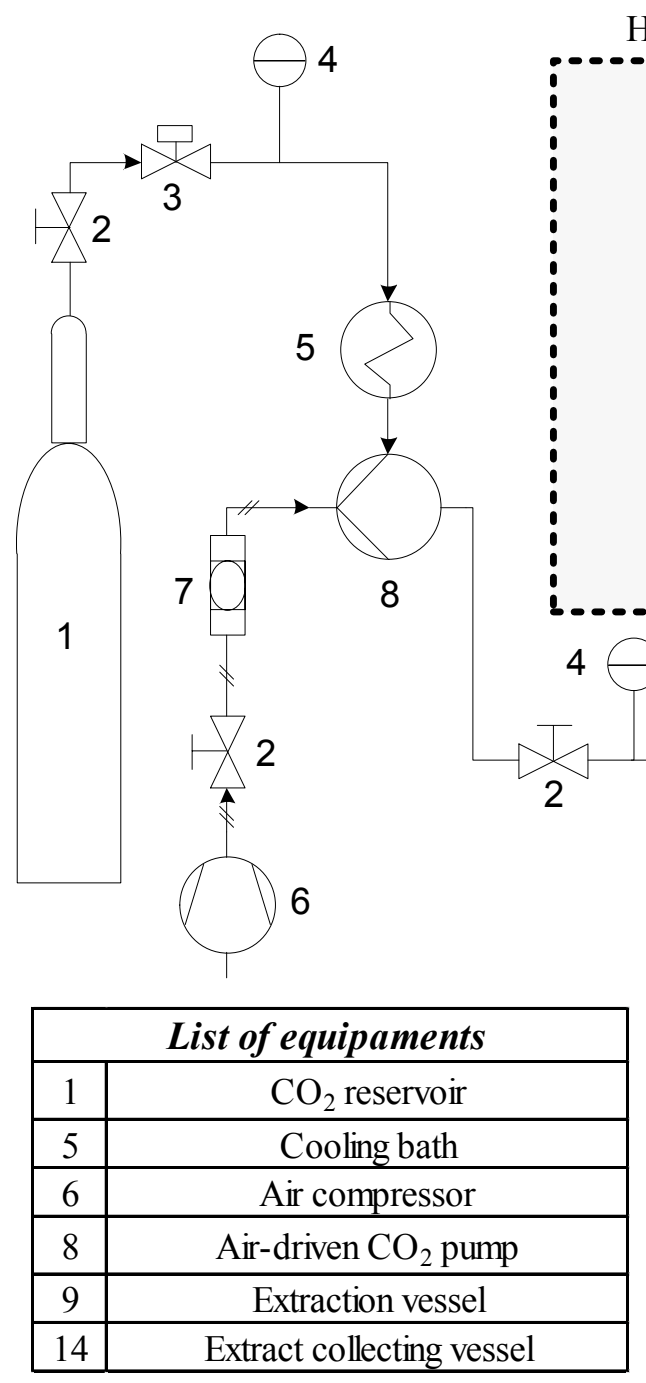

Heating chamber

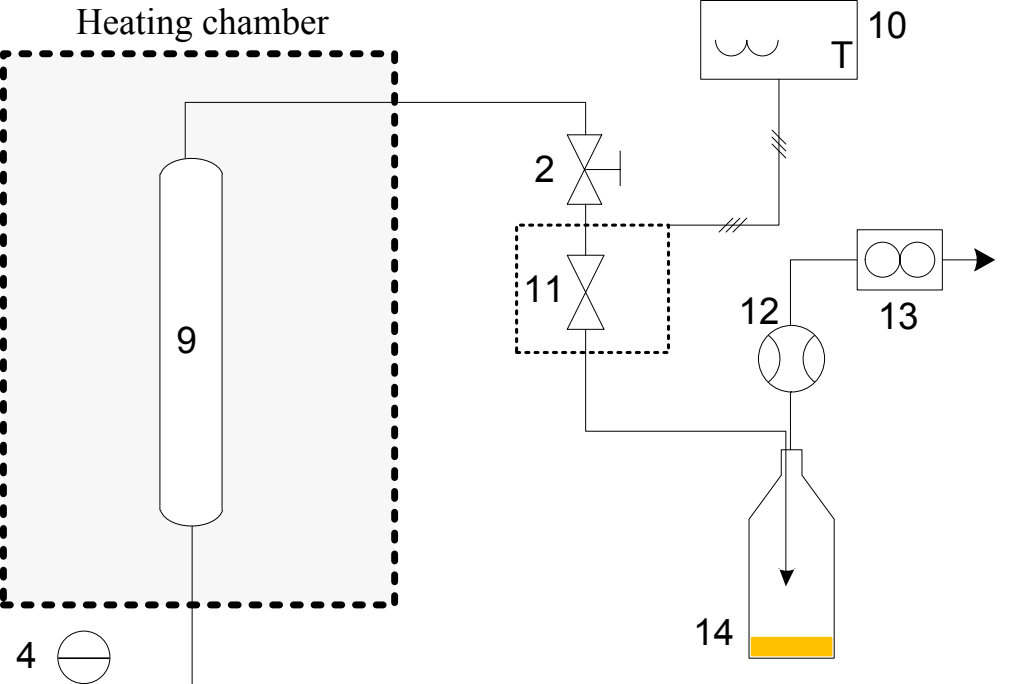

III Eletric

Extract $/ \mathrm{CO}_{2}$

Pneumatic

\begin{tabular}{|c|c|}
\hline \multicolumn{2}{|c|}{ List of valves/instruments } \\
\hline 2 & Blocking valve \\
\hline 3 & Non-return valve \\
\hline 4 & Pressure gauge \\
\hline 7 & Air filter \\
\hline 10 & Temperature controller \\
\hline 11 & Micrometering valve \\
\hline 12 & Flowmeter \\
\hline 13 & Flow totalizer \\
\hline
\end{tabular}

Scheme 2. Flow diagram for the SFE-Spe-ed experimental apparatus for extraction (adapted from Prado [25]) 


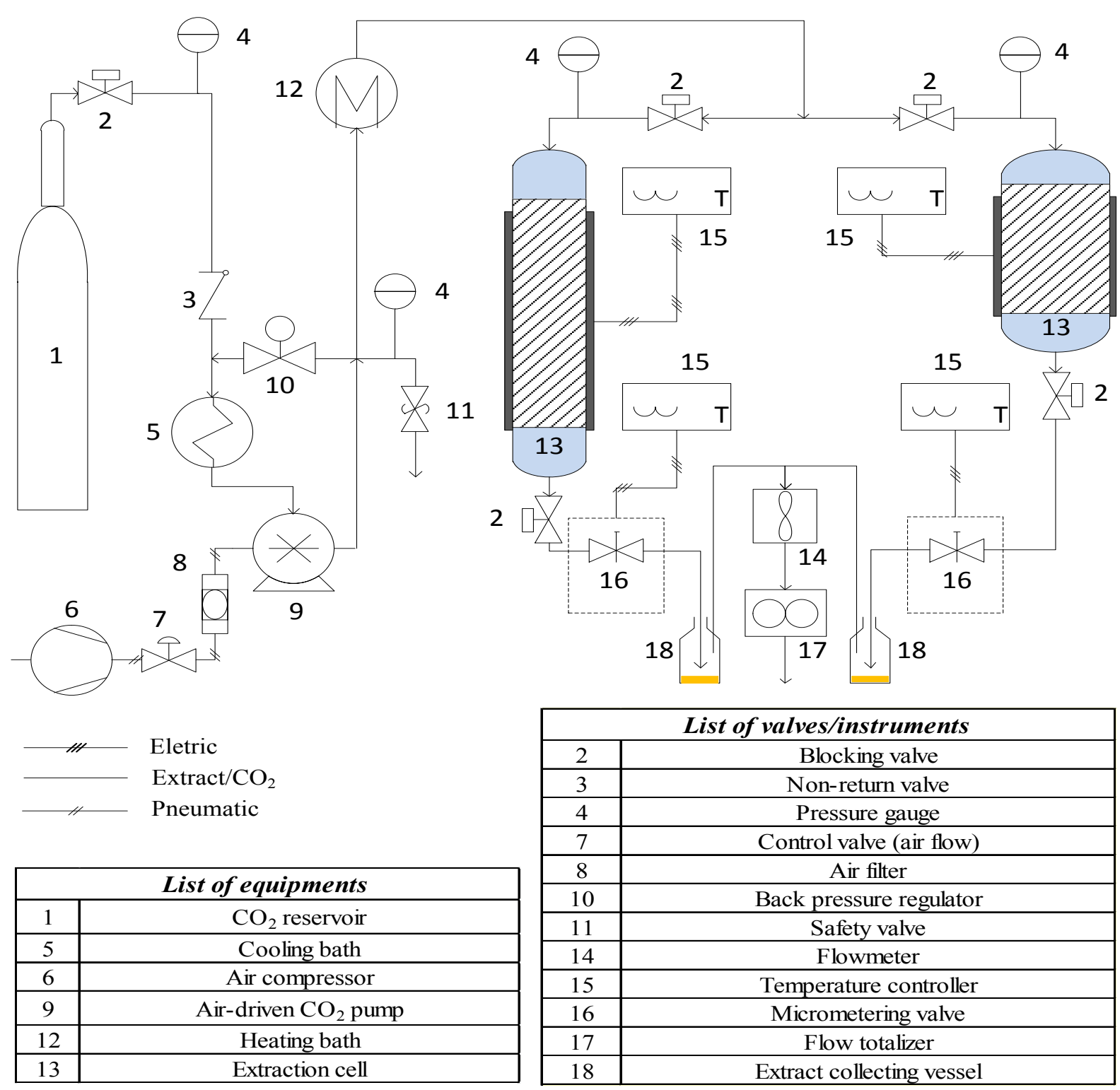

Scheme 3. Flow diagram for the SFE- $2 \times 1 \mathrm{~L}$ experimental apparatus for extraction (adapted from Zabotet al [28])

Prado et al [29] investigated the same scale-up criteria mentioned above on SFE of grape (Vitisvinifera) seed extract. The results were satisfactory because the yields were 11.9 $\mathrm{g} / 100 \mathrm{~g}$ (I) and $11.2 \mathrm{~g} / 100 \mathrm{~g}$ (II) using an S/F ratio of 8.4. The authors further tested the separation step on the SFE- $2 \times 5 \mathrm{~L}$ system using three separators of $1 \mathrm{~L}$ operating in series (Scheme). The temperature was kept at $313 \mathrm{~K}$, and pressures of $10 \mathrm{MPa}, 6 \mathrm{MPa}$ and $3 \mathrm{MPa}$ were used for the separators 1, 2 and 3, respectively. Most of extract was recovered in separator $1(86 \%)$, and the rest of it was recovered in separator 2 . There was no extract in separator 3 , which indicates that, using the operating conditions selected for separators 1 and 2, it is possible to precipitate all the extract. Similar results were obtained for extraction from clove [27].

Figure 6 shows a flow diagram for the PLE-I system, which uses pressurized liquid, generally water or ethanol, for extracting mainly polar compounds that possess chemical affinity for these solvents. To summarize, the research studies conducted at LASEFI emphasize the extraction of bioactive compounds at the highest extraction yield by optimizing process parameters through experimental work coupled with mathematical modeling. In addition, these studies investigate the chemical composition of the extracts and the functional properties, such as antioxidant activity, of the target compounds.

\subsection{Production of Micro- and Nano-particles}

Currently, novel techniques to produce micro- and nano-particles using supercritical technology are being developed to overcome the drawbacks found in conventional processes. In our research group, studies aiming to produce micrometer-scale particles have been carried out since 2009 . Santos [30] designed, assembled and tested the ARADIME apparatus, the flow diagram of which is shown in Scheme. This home-made multipurpose system is used to conduct 
experiments with pressurized fluids that allow the production of particles of functional pigments using RESS (Rapid Expansion of Supercritical Solutions) and SAS (Supercritical fluid Anti-Solvent).

Santos et al [31] demonstrated that the SAS process could be successfully utilized to co-precipitate microparticles of polyethylene glycol (PEG) loaded with bixin-rich extract. Moreover, the RESS process using ethanol as co-solvent can be effectively employed to encapsulate rutin and anthocyanin-rich extract in the PEG matrix.

Anthocyanins extracted from jabuticaba (Myrciaria cauliflora) skins were encapsulated using supercritical $\mathrm{CO}_{2}$ and ethanol as the co-solvent. Particles encapsulated by RESS at different pressures and temperatures retained the extracts' biological activity and preserved the extract's stability against light and heat degradation. The best operational conditions were $313 \mathrm{~K}$ and $20 \mathrm{MPa}$ [32].

Carotenoid particles of sub-micron size were produced using SFE with an oil-in-water emulsion. Suspensions containing stabilized carotenoids with final particle size of $344-366 \mathrm{~nm}$, an encapsulation efficiency of $34-89 \%$ and a degree of isomerization from trans- to cis-carotenoid forms in the range of $0.02-15 \%$ were obtained [33]. A novel process, known as OEPO (organic solvent extraction and online particle formation), was developed by Santos et al [34]. The process consists of the combination of Pressurized Liquid Extraction (PLE)-Supercritical Anti Solvent (SAS) precipitation, PLE-SAS co-precipitation and PLE-Supercritical Fluid Extraction of Emulsions (SFEE). This is a suitable and promising process to obtain, in only one step, different products as precipitated extract, co-precipitated extract or encapsulated extract in suspension.

All of the recent works completed at LASEFI related to this emerging technology [31-37] belong to a broader project whose overall goal is the development of alternative sustainable systems for the formation of particles of sensitive bioactive substances from many vegetable matrices.

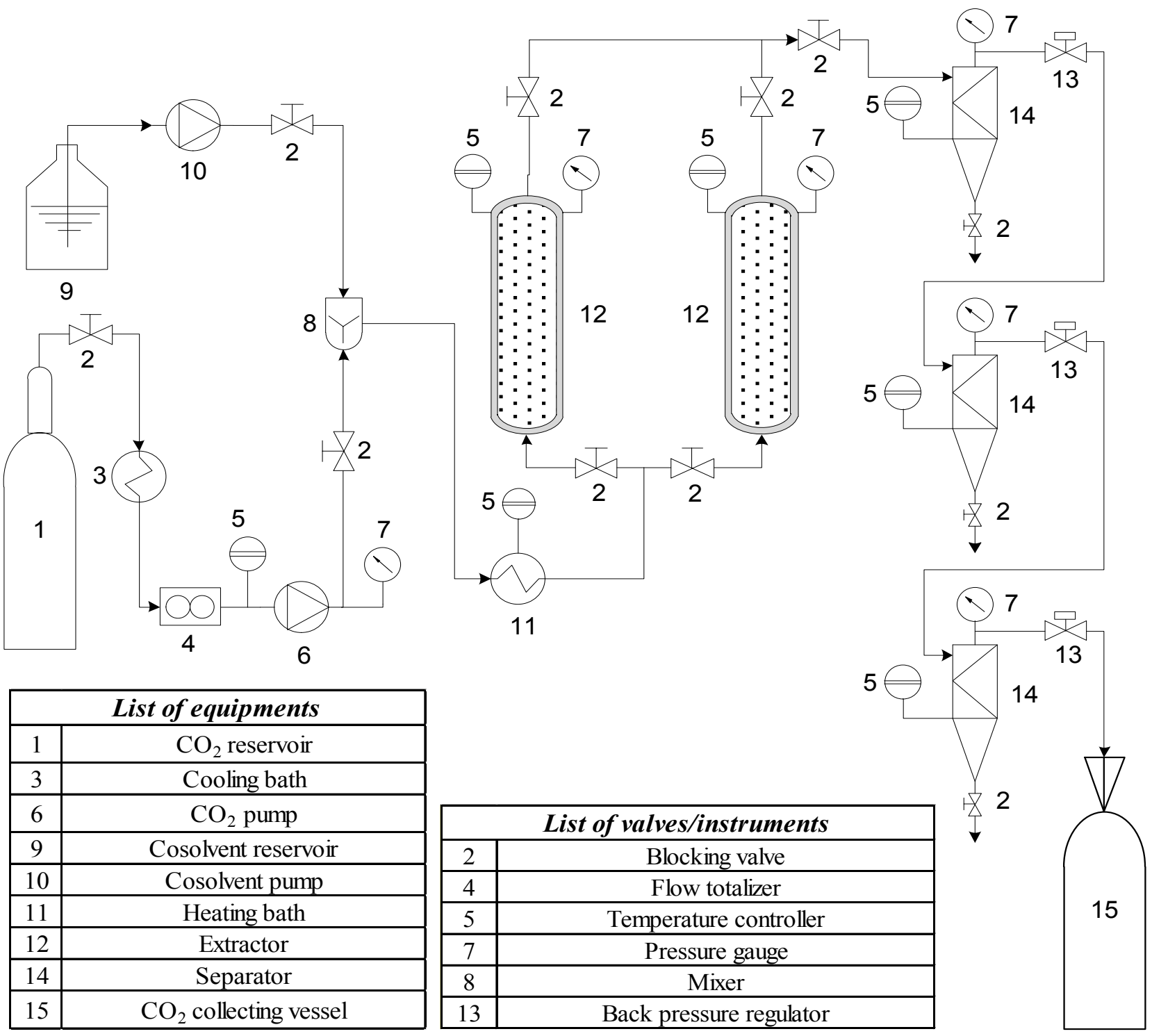

Scheme 4. Flow diagram for the SFE- $2 \times 5$ L experimental apparatus for extraction, including the co-solvent feed system (adapted from Prado [25]) 


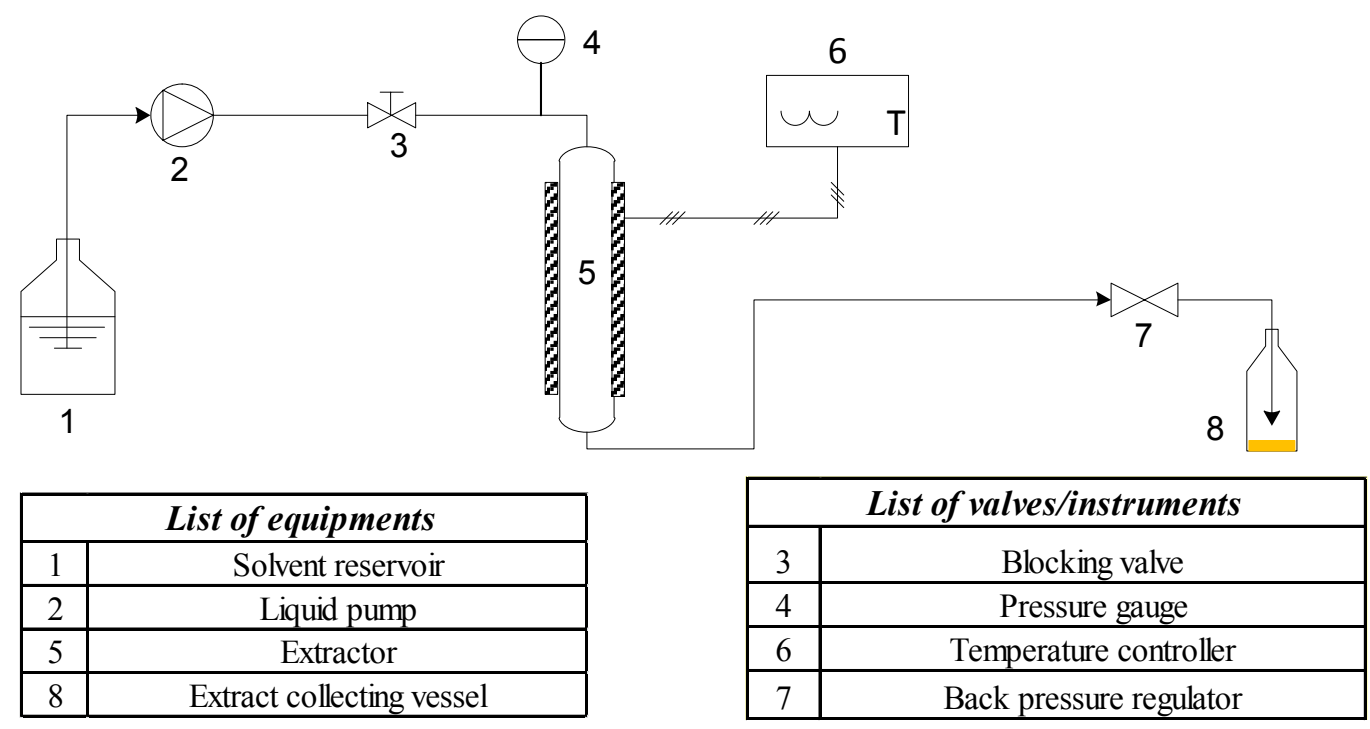

Scheme 5. Flow diagram for the PLE-I experimental apparatusfor extraction (adapted from Rodrigues et al [38])

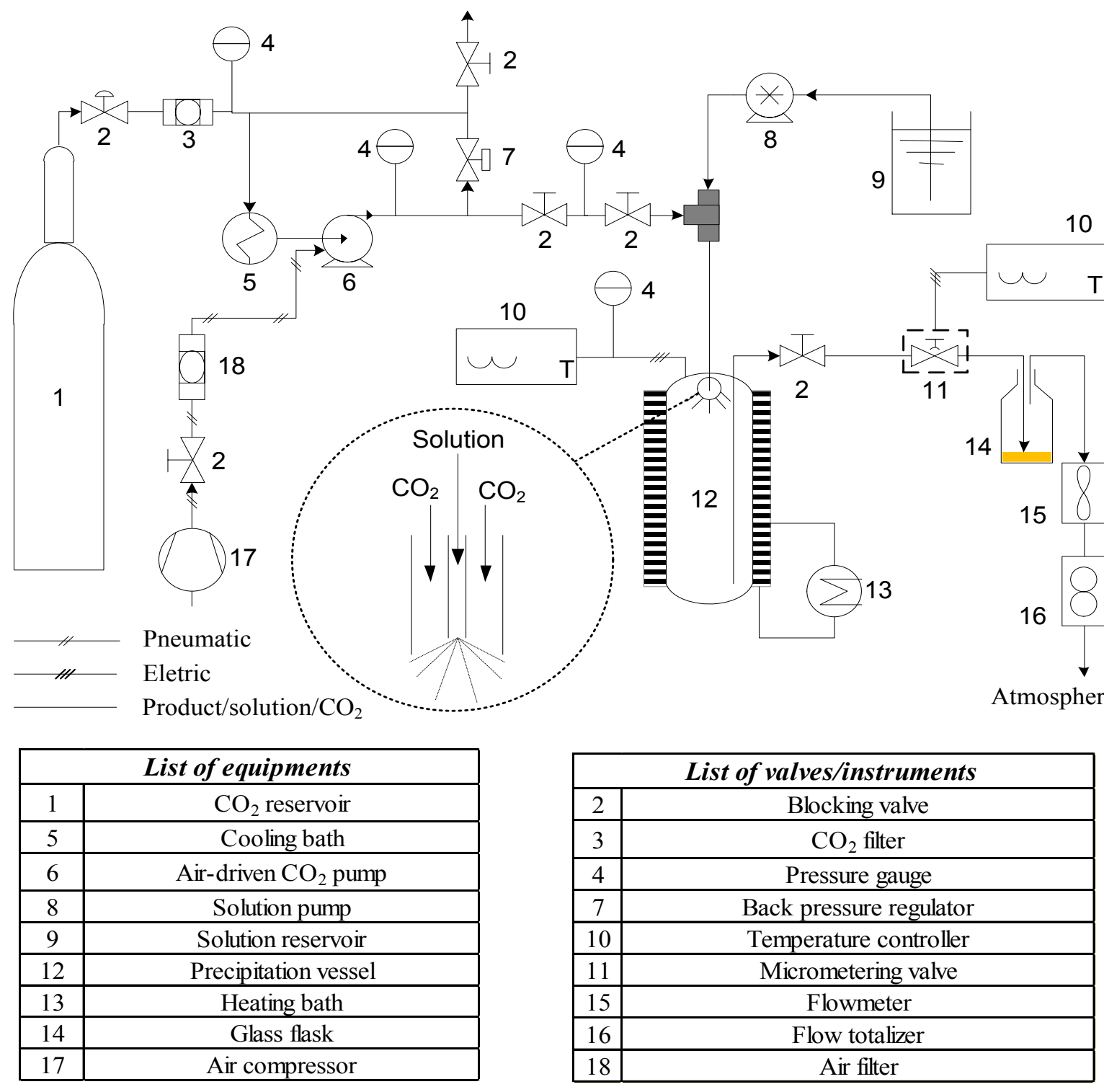

Scheme 6. Flow diagram for the ARADIME experimental apparatus for micronization (adapted from Santos [30]) 


\subsection{Hydrolysis of Agroindustrial Co-products Using Supercritical Technology}

Another research line, pursued at LASEFI since 2004, relates to the hydrolysis of agroindustrial waste using sub/supercritical water $+\mathrm{CO}_{2}$ for the production of sugars that can be eventually utilized for second-generation ethanol production. The HYDRO system (Scheme 7), containing a $0.05 \mathrm{~L}$ reactor, was designed, assembled and tested by Prado et al [39]. The system was designed to operate at pressures up to $40 \mathrm{MPa}$ and temperatures up to $673 \mathrm{~K}$. Water is pumped from reservoir 2, and if addition of $\mathrm{CO}_{2}$ is enabled, the static mixer (instrument 9) serves to homogenate the solvents before their percolation inside the reactor containing the biomass. Generally, the biomass consists of lignocellulosic material, a non-edible source of fermentable sugars widely available in the nature. To validate the HYDRO system, hydrolyses of cellulose and sugarcane bagasse were performed. The glucose equivalent concentrations in the hydrolysate fractions were approximately $6 \mathrm{~g} / 100 \mathrm{~g}$ of cellulose for a reaction time of $60 \mathrm{~min}$ and $5.9 \mathrm{~g} / 100 \mathrm{~g}$ sugarcane bagasse for a reaction time of $40 \mathrm{~min}$.

The reducing sugars obtained in the hydrolysate fractions can be used in fermentative processes for the production of renewable energy sources. This method of obtaining energy can become the basis for the development of modern industrial economies in the future. Ethanol is emerging as an efficient and economically feasible fuel. With the goal of obtaining sugar precursors for ethanol production, FollegattiRomero et al [40] performed experimental assays with the HYDRO system using cellulose with water under subcritical conditions of $457 \mathrm{~K}, 470 \mathrm{~K}$ and $482 \mathrm{~K}$ with a reaction time of $68 \mathrm{~min}$ and at a pressure of $20 \mathrm{MPa}$. The authors concluded that the results obtained were satisfactory and that the total reducing sugar content recovered at $482 \mathrm{~K}$ was the highest. At this temperature, the recovery of sugars was also the fastest.

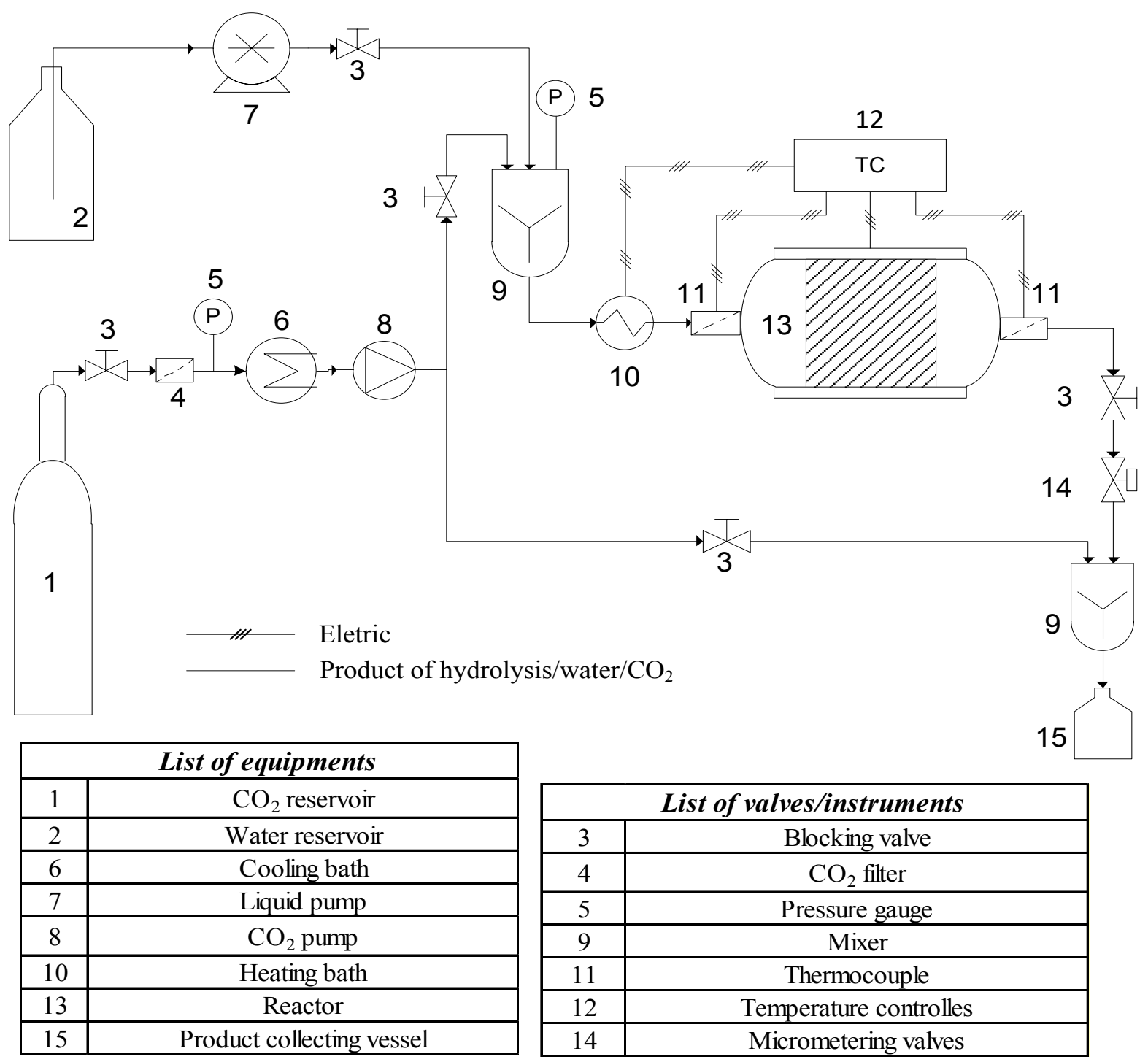

Scheme 7. Flow diagram for the HYDRO experimental apparatus for hydrolysis (adapted from Prado et al [39]) 


\section{Analytical Procedures}

Chemical characterization of the products is important to assess their qualities. At LASEFI, researchers usually perform thin layer chromatography (TLC) for qualitative analysis of the extracts. An important method of quantitative analysis is gas chromatography (GC) coupled to a flame ionization detector (FID). HPLC (high performance liquid chromatography) analyses are also performed to identify and quantify the target compounds obtained. Additionally, supercritical fluid chromatography (SFC) has been recently implemented in the laboratory. The system will be used to develop methodologies for analyzing a wide range of components (phenolic acids, catechins, flavonoids, alkaloids, carotenoids, sterols, etc.) present in different natural sources.

\section{Economic Evaluation of Processes Employing Supercritical Technology}

Processes that make use of supercritical technology are usually technically feasible. Nonetheless, detailed investigations about their economic feasibility need to be performed if these processes are to be scaled up for industrial applications. Therefore, simulations of the cost of manufacturing (COM) extracts from several botanic matrices are being developed by researchers at LASEFI. Cavalcantiet al [20] simulated the COM of jabuticaba extract obtained by SFE in extractors of various sizes using a commercial simulator. According to their results, the cost of extract production was lower than US $\$ 10.00 / \mathrm{kg}$ in a $300 \mathrm{~L}$ extractor. Veggiet al [41] compared the COM of jabuticaba extract obtained by PLE and by conventional techniques in a $300 \mathrm{~L}$ extractor. The values of COM of the extracts were US\$ $15.53 / \mathrm{kg}$ in PLE, US\$ $410.21 / \mathrm{kg}$ in ultrasound-assisted extraction and US\$ 778.42/ $\mathrm{kg}$ in Soxhlet extraction. The values of COM of extracts from Amazonian plants as buriti, pupunha and pressed palm fiber [42], annatto [24], pomegranate [19], grape [29] and sugarcane residue [27] were also simulated.

Table 2. LASEFI's research studies from 2009 to 2013

\begin{tabular}{|c|c|c|c|c|c|}
\hline Raw materials studied & $\begin{array}{l}\text { Extraction } \\
\text { methods }\end{array}$ & $\begin{array}{c}\text { Experimental } \\
\text { determinations }\end{array}$ & Extracts' characterization & Theoretical studies & References \\
\hline Annatto (Bixaorellana L.) & SFE & GYIs; OECs; X0 & $\begin{array}{c}\text { Bixin (UV-vis); Vitamin E } \\
\text { (HPLC) }\end{array}$ & $\begin{array}{l}\text { Mathematical modeling; } \\
\text { COM }\end{array}$ & [24] \\
\hline $\begin{array}{c}\text { Pomegranate } \\
\text { (Punicagranatum L.) }\end{array}$ & SFE & GYIs & $\begin{array}{c}\text { TPC (UV-vis); Chemical } \\
\text { composition (GC-MS); Aa }\end{array}$ & $\begin{array}{c}\text { Process simulation; } \\
\text { scale up; COM }\end{array}$ & [19] \\
\hline $\begin{array}{c}\text { Jabuticaba (Myrciaria } \\
\text { cauliflora) }\end{array}$ & $\begin{array}{l}\text { SFE; PLE; } \\
\text { LPSE; } \\
\text { HPCDAE; } \\
\text { UAE; ABE; } \\
\text { UAE+ABE }\end{array}$ & $\begin{array}{l}\text { GYIs; EY; OECs; } \\
\text { Recovery of } \\
\text { anthocyanins and } \\
\text { phenolic compounds }\end{array}$ & $\begin{array}{l}\text { TMA (UV-vis); TPC; Aa } \\
\text { (DPPH method); } \\
\text { Fractionated separation } \\
\text { (TLC) }\end{array}$ & $\begin{array}{l}\text { Process simulation; } \\
\text { COM; scale up }\end{array}$ & $\begin{array}{c}{[20],[34],} \\
{[41],[45-47]}\end{array}$ \\
\hline $\begin{array}{c}\text { Brazilian ginseng (Pfaffia } \\
\text { glomerata) }\end{array}$ & $\begin{array}{l}\text { SFE; PLE; } \\
\text { LPSE }\end{array}$ & OECs; EY; X0 & $\begin{array}{c}\text { Fractionated separation } \\
\text { (TLC); Ecdysteroids } \\
\text { (HPLC); Aa (DPPH method) }\end{array}$ & $\begin{array}{l}\text { Process simulation; } \\
\text { energetic analysis; } \\
\text { COM; }\end{array}$ & $\begin{array}{c}{[16],[48],} \\
{[49]}\end{array}$ \\
\hline Grape (VitisviniferaL.) & SFE & $\begin{array}{l}\text { OECs; scale up; } \\
\text { Separation step of } \\
\text { compounds } \\
\end{array}$ & $\begin{array}{c}\text { Fatty acid (GC); } \\
\text { crystallization of the oil } \\
\text { (DSC) }\end{array}$ & COM; scale up & {$[29],[50]$} \\
\hline $\begin{array}{l}\text { Clove (Eugenia } \\
\text { caryophyllus) }\end{array}$ & SFE & $\begin{array}{l}\text { OECs; scale up; } \\
\text { Separation step of } \\
\text { compounds } \\
\end{array}$ & $\begin{array}{l}\text { Chemical composition } \\
\text { (GC-FID) }\end{array}$ & $\begin{array}{l}\text { Mathematical modeling; } \\
\text { simulation and } \\
\text { optimization } \\
\end{array}$ & {$[27],[51]$} \\
\hline $\begin{array}{c}\text { Macela } \\
\text { (Achyroclinesatureioides) }\end{array}$ & SFE; LPSE & GYIs; EY; scale up & $\begin{array}{c}\text { Aa; TPC; TFC; GAC } \\
\text { (UV-vis); chemical } \\
\text { composition (GC-FID) } \\
\end{array}$ & $\begin{array}{l}\text { Mathematical modeling; } \\
\text { COM }\end{array}$ & $\begin{array}{l}{[18],[21]} \\
{[52],[53]}\end{array}$ \\
\hline $\begin{array}{c}\text { Chamomile } \\
\text { (Chamomillarecutita L.) }\end{array}$ & SFE & OECs & $\begin{array}{c}\text { Chemical composition } \\
\text { (GC-FID) }\end{array}$ & $\begin{array}{l}\text { Mathematical modeling; } \\
\text { process optimization }\end{array}$ & [23] \\
\hline $\begin{array}{c}\text { Vetiver } \\
\text { (Vetiveriazizanioides) }\end{array}$ & SFE & $\begin{array}{c}\text { Amount of extract in } \\
\text { the light and heavy } \\
\text { phases }\end{array}$ & $\begin{array}{c}\text { Aa (DPPH method); TPC } \\
\text { (UV-vis); chemical } \\
\text { composition (GC-FID) } \\
\end{array}$ & $\begin{array}{c}\text { Simulation of the phases } \\
\text { equilibrium }\end{array}$ & [54] \\
\hline $\begin{array}{c}\text { Ginger } \\
\text { (Zingiberofficinale) }\end{array}$ & SFE & $\begin{array}{l}\text { GYIs; OECs; EY; } \\
\text { scale up }\end{array}$ & $\begin{array}{c}\text { Fractional separation (TLC); } \\
\text { chemical composition } \\
\text { (GC-FID) }\end{array}$ & Scale up & [27] \\
\hline Jambul (Syzygiumcumini) & UAE; ABE & $\begin{array}{l}\text { EY; Anthocyanin } \\
\text { extraction }\end{array}$ & $\begin{array}{l}\text { TPC; TMA (UV-vis); TLC; } \\
\text { Electrospray Ionization } \\
\text { Tandem Mass Spectrometry }\end{array}$ & - & [55] \\
\hline $\begin{array}{c}\text { Jatoba } \\
\text { (Hymenaeacourbaril L.) }\end{array}$ & UAE; ABE & OECs; EY & $\begin{array}{l}\text { TPC (UV-vis); Aa (DPPH } \\
\text { method); TLC; Polyphenols } \\
\text { (HPLC) }\end{array}$ & Scale up & [56] \\
\hline
\end{tabular}




\section{Summary of the Current Scientific Investigations Conducted at LASEFI}

Table 2 shows a summary of the recent projects developed at LASEFI coveringthe application of supercritical fluids to several experimental processes. The large biodiversity of bioresources in Brazil has favored the use of different raw materials, as annatto (Bixaorellana L.), which contains tocotrienols and bixin [24] to be used in the treatment of cardiovascular diseases [43] and to be applied as colorant in food processing [44], respectively.

\section{Concluding Remarks}

Some progress has been made compared to the recent research results. For instance, one ongoing projectaims to develop an integrated analysis system by gathering the sample preparing with the chromatographic analyses. The sample preparing step is done by pressurized liquid extraction (PLE) assisted by ultrasound or supercritical fluid extraction (SFE) online coupled to a purification step using solid phase extraction (SPE). This integrated system will be applied to develop methodologies for determining a wide range of bioactive compounds.

Likewise, producing high-added vegetal extracts using green processes is a continuous effort done by the research group. Emerging applications of supercritical fluids, such as micronization and the encapsulation of nanoparticles, are being studied to produce several phytochemicals useful in the food and pharmaceutical industries. The processes include the encapsulation of nanoparticles containing target components from annatto, jabuticaba waste and Brazilian ginseng. Moreover, the use of environmentally friendly pressurized fluid technologies to obtain products from biomass has shown encouraging results. Another ongoing project is focused on the attainment of multiple products through a combination of different processes and sequenced with the use of multiple fluids. The goal is to use the knowledge and available tools on energy integration and life cycle analysis seeking an integral use of all parts of the Brazilian ginseng (root and aerial parts), expecting a Brazilian ginseng biorefinery based on supercritical technology.

Process intensification, process integration, extraction in continuous mode and hydrolysis of agroindustrial residues are also ongoing projects performed at LASEFI. In summary, the present objectives of the research group revolve around the scale up of the laboratory processes for the production of various extracts to effectively start up an industrial plant employing supercritical technology in Latin America.

\section{ACKNOWLEDGMENTS}

Giovani L. Zabot thanks FAPESP (2011/23665-2) and Moyses N. Moraes thanks CAPES for granting their Ph.D. assistantships. M. A. A. Meireles acknowledges a productivity grant (301301/2010-7) from CNPq. The authors acknowledge the financial support from CAPES, CNPq and FAPESP.

\section{REFERENCES}

[1] M. N. Moraes, G. L. Zabot, J. M. Prado, M. A. A. Meireles, "Obtaining Antioxidants from Botanic Matrices Applying Novel Extraction Techniques", Food and Public Health, vol.3, no.4, pp.195-214, 2013.

[2] G. A. Núñez, C. A. Gelmi, J. M. del Valle, "Simulation of a supercritical carbon dioxide extraction plant with three extraction vessels", Computers and Chemical Engineering, vol.35, no.12, pp.2687-2695, 2011.

[3] D. A. Oliveira, A. A. Salvador, A. Smânia, E. F. A. Smânia, M. Maraschin, S. R. S. Ferreira, "Antimicrobial activity and composition profile of grape (Vitis vinifera) pomace extracts obtained by supercritical fluids", Journal of Biotechnology, vol.164, no.3, pp.423-432, 2013.

[4] G. Brunner, N. T. Machado, "Process design methodology for fractionation of fatty acids from palm fatty acid distillates in countercurrent packed columns with supercritical $\mathrm{CO}_{2}$ ", Journal of Supercritical Fluids, vol.66, pp.96-110, 2012.

[5] E. Kiran, "Foaming strategies for bioabsorbable polymers in supercritical fluid mixtures. Part I. Miscibility and foaming of poly(l-lactic acid) in carbon dioxide + acetone binary fluid mixtures", Journal of Supercritical Fluids, vol.54, no.3, pp.308-319, 2010.

[6] J. P. S. Queiroz, M. D. Bermejo, M. J. Cocero, "Kinetic model for isopropanol oxidation in supercritical water in hydrothermal flame regime and analysis", Journal of Supercritical Fluids, vol.76, pp.41-47, 2013.

[7] S. Machmudah, Wahyudiono, N. Takada, H. Kanda, K. Sasaki, M. Goto, "Fabrication of gold and silver nanoparticles with pulsed laser ablation under pressurized $\mathrm{CO}_{2}$ ", Advances in Natural Sciences: Nanoscience and Nanotechnology, vol.4, no.4, 2013.

[8] D. Villanueva Bermejo, E. Ibáñez, R. P. Stateva, T. Fornari, "Solubility of $\mathrm{CO}_{2}$ in ethyl lactate and modeling of the phase behavior of the $\mathrm{CO}_{2}+$ ethyl lactate mixture", Journal of Chemical and Engineering Data, vol.58, no.2, pp.301-306, 2013.

[9] V. Marulanda, G. Bolaños, "Supercritical water oxidation of a heavily PCB-contaminated mineral transformer oil: Laboratory-scale data and economic assessment", Journal of Supercritical Fluids, vol.54, no.2, pp.258-265, 2010.

[10] H. Mhemdi, E. Rodier, N. Kechaou, J. Fages, "A supercritical tuneable process for the selective extraction of fats and essential oil from coriander seeds", Journal of Food Engineering, vol.105, no.4, pp.609-616, 2011.

[11] H. Machida, M. Takesue, R. L. Smith, "Green chemical processes with supercritical fluids: Properties, materials, separations and energy", Journal of Supercritical Fluids, vol.60, pp.2-15, 2011.

[12] J. W. King, "Supercritical fluid-based extraction/processing: Then and now", International News on Fats, Oils and Related 
Materials, vol.23, no.2, pp.124-128, 2012.

[13] D. Ciftci, M. D. A. Saldaña, "Enzymatic synthesis of phenolic lipids using flaxseed oil and ferulic acid in supercritical carbon dioxide media", Journal of Supercritical Fluids, vol.72, pp.255-262, 2012.

[14] K. Gairola, I. Smirnova, "Hydrothermal pentose to furfural conversion and simultaneous extraction with $\mathrm{SC}-\mathrm{CO}_{2}-$ Kinetics and application to biomass hydrolysates", Bioresource Technology, vol.123, pp.592-598, 2012.

[15] S. Kazemi, V. Belandria, N. Janssen, D. Richon, C. J. Peters, M. C. Kroon, "Solubilities of ferrocene and acetylferrocene in supercritical carbon dioxide", Journal of Supercritical Fluids, vol.72, pp.320-325, 2012.

[16] P. F. Leal, M. B. Kfouri, F. C. Alexandre, F. H. R. Fagundes, J. M. Prado, M. H. Toyama, M. A. A. Meireles, "Brazilian ginseng extraction via LPSE and SFE: global yields, extraction kinetics, chemical composition and antioxidant activity", J. Supercrit. Fluids, vol.54, no.1, pp.38-45, 2010.

[17] M. A. A. Meireles, P. F. Leal, F. C. Alexandre, M. B. Kfouri, "Extraction process of active substances from brazilian ginseng", PI0900551-0A2, Brazil, 2009.

[18] T. M. Takeuchi, M. L. Rubano, M. A. A. Meireles, "Characterization and functional properties of macela (Achyrocline satureioides) extracts obtained by supercritical fluid extraction using mixtures of $\mathrm{CO}_{2}$ plus ethanol", Food Bioproc. Technol., vol.3, no.6, pp.804-812, 2010.

[19] R. N. Cavalcanti, H. J. J. Navarro-Díaz, D. T. Santos, M. A. Rostagno, M. A. A. Meireles, "Supercritical carbon dioxide extraction of polyphenols from pomegranate (Punica granatum L.) leaves: chemical composition, economic evaluation and chemometric approach", J. Food Research, vol.1, no.3, pp.282-294, 2012.

[20] R. N. Cavalcanti, P. C. Veggi, M. A. A. Meireles, "Supercritical fluid extraction with a modifier of antioxidant compounds from jabuticaba (Myrciaria cauliflora) byproducts: economic viability", Procedia Food Sci., vol.1, pp.1672-1678, 2011.

[21] P. C. Veggi, "Obtaining vegetable extracts by different extraction methods: experimental study and process simulation", Master Thesis, University of Campinas/ Brazil/ Department of Food Engineer, Campinas-SP/Brazil, 2009.

[22] M. A. A. Meireles, P. T. V. Rosa, "Extraction and purification process of artemisin from solid mass of Artemisia annua using carbon dioxide", PI0903275-4A2, Brazil, 2009.

[23] E. Rahimi, J. M. Prado, G. Zahedi, M. A. A. Meireles, "Chamomile extraction with supercritical carbon dioxide: mathematical modeling and optimization", J. Supercrit. Fluids, vol.56, no.1, pp.80-88, 2011.

[24] C. L. C. Albuquerque, M. A. A. Meireles, "Defatting of annatto seeds using supercritical carbon dioxide as a pretreatment for the production of bixin: experimental, modeling and economic evaluation of the process", J. Supercrit. Fluids, vol.66, pp.86-95, 2012.

[25] J. M. Prado, "Scale-up study of supercritical fluid extraction process in fixed bed", Doctoral in Food Engineering, Unicamp/Food Engineering, Campinas-Brazil, 2010.

[26] G. L. Zabot, M. N. Moraes, M. A. A. Meireles, "Supercritical fluid extraction of bioactive compounds from botanic matrices: experimental data, process parameters and economical evaluation", Recent Patents Eng., vol.6, no.3, pp.182-206, 2012.

[27] J. M. Prado, G. H. C. Prado, M. A. A. Meireles, "Scale-up study of supercritical fluid extraction process for clove and sugarcane residue", J. Supercrit. Fluids, vol.56, no.3, pp.231-237, 2011.

[28] G. L. Zabot, M. N. Moraes, A. J. Petenate, M. A. A. Meireles, "Influence of the bed geometry on the kinetics of the extraction of clove bud oil with supercritical $\mathrm{CO}_{2}$ ", Journal of Supercritical Fluids, 2013, In press.

[29] J. M. Prado, I. Dalmolin, N. D. D. Carareto, R. C. Basso, A. J. A. Meirelles, J. V. Oliveira, E. A. C. Batista, M. A. A. Meireles, "Supercritical fluid extraction of grape seed: process scale-up, extract chemical composition and economic evaluation", J. Food Eng., vol.109, no.2, pp.249-257, 2012.

[30] D. T. Santos, "Extraction, micronization and stabilization of functional pigments: construction of multipurpose unit for pressurized fluid process development", Doctoral Thesis, University of Campinas/Brazil, Department of Food Engineering, Campinas-SP/Brazil, 2011.

[31] D. T. Santos, M. A. A. Meireles, "Micronization and encapsulation of functional pigments using supercritical carbon dioxide", J. Food Process Eng., vol.36, no.1, pp.36-49, 2011.

[32] D. T. Santos, J. Q. Albarelli, M. M. Beppu, M. A. A. Meireles, "Stabilization of anthocyanin extract from jabuticaba skins by encapsulation using supercritical $\mathrm{CO}_{2}$ as solvent", Food Research Int., vol.50, no.0, pp.617-624, 2012.

[33] D. T. Santos, A. Martin, M. A. A. Meireles, M. J. Cocero, "Production of stabilized sub-micrometric particles of carotenoids using supercritical fluid extraction of emulsions", J. Supercrit. Fluids, vol.61, pp.167-174, 2012.

[34] D. T. Santos, D. F. Barbosa, K. Broccolo, M. T. M. S. Gomes, R. Vardanega, M. A. A. Meireles, "Pressurized organic solvent extraction with on-line particle formation by supercritical anti solvent processes", Food Public Health, vol.2, no.6, pp.231-240, 2012.

[35] M. T. M. S. Gomes, D. T. Santos, M. A. A. Meireles, "Trends in Particle Formation of Bioactive Compounds Using Supercritical Fluids and Nanoemulsions", Food Public Health, vol.2, pp.142-152, 2012.

[36] D. T. Santos, D. F. Barbosa, R. Vardanega, J. Q. Albarelli, M. A. A. Meireles, "Experimental and simulation study on formulation of clove essential oil products using alternative surfactant", J. Coll. Sci. Biotech., vol.2, pp.112-122, 2013.

[37] D. T. Santos, D. F. Barbosa, R. Vardanega, M. T. M. S. Gomes, M. A. A. Meireles, "Novel method to produce emulsions containing essential oils from saponin-rich pressurized aqueous plant extracts", J. Coll. Sci. Biotech., vol.2, pp.93-99, 2013.

[38] L. M. Rodrigues, S. C. Alcázar-Alay, A. J. Petenate, M. A. A. Meireles, "Bixin extraction from defatted annatto seeds", Comptes Rendus Chimie, 2014, In press.

[39] J. M. Prado, L. A. Follegatti-Romero, F. P. Cardenas-Toro, T. Forster-Carneiro, M. A. Rostagno, M. A. A. Meireles, 2012, Cellulose and sugarcane bagasse hydrolysis using subcritical 
water, Proc. 10th International Symposium on Supercritical Fluids, San Francisco, CA-USA.

[40] L. A. Follegatti-Romero, J. M. Prado, T. F. Carneiro, F. P. Cardenas-Toro, M. A. Rostagno, M. A. A. Meireles, 2012, Semi-batch equipment for the hydrolysis of lignocellulosic raw materials, Proc. 10th International Symposium on Supercritical Fluids, San Francisco, CA-USA.

[41] P. C. Veggi, D. T. Santos, M. A. A. Meireles, "Anthocyanin extraction from Jabuticaba (Myrciaria cauliflora) skins by different techniques: economic evaluation", Procedia Food Sci., vol.1, pp.1725-1731, 2011.

[42] J. M. Prado, A. R. Assis, M. R. Marostica, M. A. A. Meireles, "Manufacturing cost of supercritical-extracted oils and carotenoids from amazonian plants", J. Food Proc. Eng., vol.33, no.2, pp.348-369, 2010.

[43] B. Tan, "Appropriate spectrum vitamin E and new perspectives on desmethyl tocopherols and tocotrienols", Journal of American Nutraceutical Association, vol.8, pp.35-42, 2005.

[44] V. Akshatha, P. Giridhar, G. A. Ravishankar, "Morphological diversity in Bixa orellana L. and variations in annatto pigment yield", Journal of Horticultural Science and Biotechnology, vol.86, pp.319-324, 2011.

[45] D. T. Santos, M. A. A. Meireles, "Optimization of bioactive compounds extraction from jabuticaba (Myrciaria cauliflora) skins assisted by high pressure $\mathrm{CO}_{2}$ ", Innov. Food Sci. Emerg. Technol., vol.12, no.3, pp.398-406, 2011.

[46] D. T. Santos, P. C. Veggi, M. A. A. Meireles, "Extraction of antioxidant compounds from jabuticaba (Myrciaria cauliflora) skins: yield, composition and economical evaluation", J. Food Eng., vol.101, no.1, pp.23-31, 2010.

[47] D. T. Santos, C. L. C. Albuquerque, M. A. A. Meireles, "Antioxidant dye and pigment extraction using a homemade pressurized solvent extraction system", Procedia Food Sci., vol.1, pp.1581-1588, 2011.

[48] D. T. Santos, J. Q. Albarelli, M. A. A. Meireles, "Simulation of an integrated sustainable production of extract from Brazilian ginseng roots with a cogeneration plant", Chem.
Eng. Transactions, vol.29, pp.91-96, 2012.

[49] R. Vardanega, D. T. Santos, I. C. N. Debien, M. A. A. Meireles, 2012, Pressurized liquid extraction of bioactive compounds from brazilian ginseng roots (Pfaffia glomerata), Proc. 16th world congress of food science and technology, Foz do Iguaçu-PR/Brazil.

[50] A. M. Farías-Campomanes, M. A. Rostagno, M. A. A. Meireles, "Production of polyphenol extracts from grape bagasse using supercritical fluids: yield, extract composition and economic evaluation", J. Supercrit. Fluids, vol.77, pp.70-78, 2013.

[51] T. Hatami, M. A. A. Meireles, G. Zahedi, "Mathematical modeling and genetic algorithm optimization of clove oil extraction with supercritical carbon dioxide", J. Supercrit. Fluids, vol.51, no.3, pp.331-338, 2010.

[52] T. Hatami, R. N. Cavalcanti, T. M. Takeuchi, M. A. A. Meireles, "Supercritical fluid extraction of bioactive compounds from macela (Achyrocline satureioides) flowers: kinetic, experiments and modeling", J. Supercrit. Fluids, vol.65, pp.71-77, 2012.

[53] A. R. Assis, "Assembly, test and validation of a supercritical extraction unit with recycle and continuous operation", Doctoral Thesis, University of Campinas/Brazil, Department of Food Engineering, Campinas-SP/Brazil, 2010.

[54] T. M. Takeuchi, "Supercritical extraction of macela, clove and vetiver: technological and economical aspects", Doctoral Thesis, University of Campinas/Brazil, Department of Food Engineering, Campinas-SP/Brazil, 2009.

[55] D. T. Santos, R. N. Cavalcanti, M. A. Rostagno, C. L. Queiroga, M. N. Eberlin, M. A. A. Meireles, "Extraction of polyphenols and anthocyanins from the jambul (Syzygium cumini) fruit peels", Food Public Health, vol.3, no.1, pp.12-20, 2013.

[56] P. C. Veggi, D. T. Santos, A. S. Fabiano-Tixier, C. Bourvellec, M. A. A. Meireles, F. Chemat, "Ultrasound-assisted extraction of polyphenols from jatoba (Hymenaea courbaril L. var stilbocarpa) bark", Food Public Health, vol.3, no.3, pp.119-129, 2013. 